\author{
A. Daşdemir* \\ Kastamonu University, Kastamonu, Turkey \\ (E-mail: ahmetdasdemir37@gmail.com)
}

\title{
On Hadamard Product of Hypercomplex Numbers
}

\begin{abstract}
Certain product rules take various forms in the set of hypercomplex numbers. In this paper, we introduced a new multiplication form of the hypercomplex numbers that would be called «the Hadamard product», inspired by the analogous product in the real matrix space, and investigated some algebraic properties of that, including the norm of inequality. In particular, we extended our new definition and its applications to the complex matrix theory.
\end{abstract}

Keywords: Quaternion product, dot product, Hadamard product, hypercomplex number.

\section{Introduction}

In 1843, the Irish mathematician Sir William Rowan Hamilton introduced quaternions as an extension of complex numbers to higher spatial dimensions [1]. The set of real quaternions is often denoted by $\mathbb{H}$ in honor of its discoverer and is defined as follows:

$$
\mathbb{H}=\left\{q=q_{0}+\tilde{q}: \tilde{q}=i q_{1}+j q_{2}+k q_{3} \text { and } q_{0}, q_{1}, q_{2}, q_{3} \in \mathbb{R}\right\},
$$

where $q_{0}$ is called the scalar part of $q$, and $\tilde{q}$ is called its vector part. The scalar and vector parts of a quaternion $q$ are denoted by $S c(q)$ and $V e c(q)$, respectively. The monographs [2], [3] present well-known systematic investigations on the subject. In addition, the papers [4], [5] include some interesting applications of the quaternions.

One can apply the Cayley-Dickson process (also known as Cayley-Dickson doubling) this process to the complex numbers quaternions $(\operatorname{dim} 4)$, octonions $(\operatorname{dim} 8)$, sedenions $(\operatorname{dim} 16), \ldots, 2^{N}$-ons $\left(\operatorname{dim} 2^{N}\right)$ in succession. Each one is a sub-algebra of all the preceding ones. Note that an increase in the dimension of the algebra causes the loss of certain algebraic properties. For example, quaternions do not possess the commutative property that complex numbers possess, and octonion algebra loses the associative property. These losses often lead to unexpected results.

A $2^{N}$-ons hyper-complex number is regarded as a linear combination of a canonical basis set of this algebra in the form

$$
\omega=\sum_{i=1}^{2^{N}} w_{i} \vec{e}_{i}=w_{1} \vec{e}_{1}+w_{2} \vec{e}_{2}+\cdots+w_{2^{N}} \vec{e}_{2^{N}},
$$

where $\vec{e}_{i}$ refers to the components of the basis set and $w_{i}$ refers to real numbers. Note that the product of any two values of $\vec{e}_{i}$ is linearly dependent on $\vec{e}_{1}, \vec{e}_{2}, \cdots, \vec{e}_{2^{N}}$. Consider that algebraic properties of the hypercomplex numbers are investigated in [6-9]. For example, Table 1 summarizes the multiplication rules for the basis vectors of the quaternion and octonion algebras. This table is provided by Cawagas in reference [10]. The conjugate of $\omega$ is as follows:

$$
\omega^{*}=w_{1} \vec{e}_{1}-\sum_{i=2}^{2^{N}} w_{i} \vec{e}_{i}=w_{1} \vec{e}_{1}-w_{2} \vec{e}_{2}-\cdots-w_{2^{N}} \vec{e}_{2^{N}}
$$

and its norm is

$$
N(\omega)=\sqrt{\sum_{i=1}^{2^{N}} w_{i}^{2}}
$$

* Corresponding author.

E-mail: ahmetdasdemir37@gmail.com 
The multiplication rules for quaternions and octonions

\begin{tabular}{|c|cccccccc|}
\hline$\cdot$ & 0 & 1 & 2 & 3 & 4 & 5 & 6 & 7 \\
\hline 0 & 0 & 1 & 2 & 3 & 4 & 5 & 6 & 7 \\
1 & 1 & -0 & 3 & -2 & 5 & -4 & -7 & 6 \\
2 & 2 & -3 & -0 & 1 & 6 & 7 & -4 & -5 \\
3 & 3 & 2 & -1 & -0 & 7 & -6 & 5 & -4 \\
4 & 4 & -5 & -6 & -7 & -0 & 1 & 2 & 3 \\
5 & 5 & 4 & -7 & 6 & -1 & -0 & -3 & 2 \\
6 & 6 & 7 & 4 & -5 & -2 & 3 & -0 & -1 \\
7 & 7 & -6 & 5 & 4 & -3 & -2 & 1 & -0 \\
\hline
\end{tabular}

In this paper, we define a convenient operation between two hypercomplex numbers $u$ and $v$ as the Hadamard product $u \circ v$. It turns out that the Hadamard product of hypercomplex numbers is the analog of the Hadamard product of matrices. In addition, we show certain algebraic properties of such a product. This definition was developed particularly to characterize certain structures while working on specific quaternion sequences.

Before presenting our definition and results, we recall the following multiplication rules on the set of $\mathbb{H}$.

Let $p, q$, and $r$ be any three quaternions.

- The quaternion multiplication of $p$ and $q$ is defined as follows:

$$
p q=u_{0}+i u_{1}+j u_{2}+k u_{3},
$$

where $u_{0}=p_{0} q_{0}-p_{1} q_{1}-p_{2} q_{2}-p_{3} q_{3}, u_{1}=p_{1} q_{0}+p_{0} q_{1}-p_{3} q_{2}+p_{2} q_{3}, u_{2}=p_{2} q_{0}+p_{3} q_{1}+p_{0} q_{2}-p_{1} q_{3}$ and $u_{3}=p_{3} q_{0}-p_{2} q_{1}+p_{1} q_{2}+p_{0} q_{3}$.

- The dot product of $p$ and $q$ is a real number that is defined by

$$
p . q=p_{0} q_{0}+p_{1} q_{1}+p_{2} q_{2}+p_{3} q_{3} .
$$

- The cross product is defined by

$$
\tilde{p} \times \tilde{q}=\operatorname{Vec}(\tilde{p} \tilde{q}) .
$$

- The mixed product is defined by

$$
(\tilde{p}, \tilde{q}, \tilde{r})=\tilde{p} .(\tilde{q} \times \tilde{r}) .
$$

- The quaternion outer product of $p$ and $q$ is defined by

$$
(p, q)=p_{0} \tilde{q}-q_{0} \tilde{p}-\tilde{p} \times \tilde{q} .
$$

- The even product of $p$ and $q$ is defined by

$$
[p, q]=p_{0} q_{0}-\tilde{p} \tilde{q}-p_{0} \tilde{q}+q_{0} \tilde{p} .
$$

\section{Main Results}

Let us denote the set of all $2^{N}$-ons hypercomplex numbers in the following form:

$$
\mathbb{O}=\left\{w=w_{1} \overrightarrow{e_{1}}+\tilde{w}: \tilde{w}=w_{l} \overrightarrow{e_{l}}, l=2,3, \ldots, 2^{N} \text { and } w_{l} \in \mathbb{R}\right\},
$$

where $\overrightarrow{e_{i}}$ refers to the components of the basis set. Throughout this paper, $i, j=1, \ldots, 2^{N}$ and $l=2,3, \ldots, 2^{N}$. Note that the multiplication rule

$$
{\overrightarrow{e_{1}}}^{2}=1,{\overrightarrow{e_{l}}}^{2}=-1 \text {, and } \overrightarrow{e_{i}} \overrightarrow{e_{j}}+\overrightarrow{e_{j}} \overrightarrow{e_{i}}=0 \text { for } i \neq j
$$

is valid. At this instance and further in the document, repeated indices are summed over their ranges unless specified otherwise. We can reduce our results to particular cases depending on the choice of $N$. Clearly, we 
successively obtain the well-known complex numbers for $N=1$, quaternions for $N=2$, octonions for $N=3$, sedenions for $N=4, \ldots, 2^{N}$-ons for $N$ by starting from the real numbers for $N=0$.

Now we give the following definition.

Definition 1. For two hypercomplex numbers $p=p_{i} \vec{e}_{i}$ and $q=q_{i} \vec{e}_{i}$, the Hadamard product of $p$ and $q$ over the set $\mathbb{O}$ is defined as follows:

$$
p \circ q=p_{i} q_{i} \vec{e}_{i}=p_{1} q_{1} \vec{e}_{1}+p_{2} q_{2} \vec{e}_{2}+p_{3} q_{3} \vec{e}_{3}+\cdots+p_{2^{N}} q_{2^{N}}{\overrightarrow{e_{2}}}_{2^{N}}
$$

where $p_{i}, q_{i} \in \mathbb{R}$.

This definition involves an element-wise product of hypercomplex numbers similar to the Hadamard product defined on the set of matrices. As a result, this inspired the name «Hadamard product» of hypercomplex numbers. To avoid confusion, juxtaposition of hypercomplex numbers will imply the usual product of hypercomplex numbers, and we will always employ the notation «o» for the Hadamard product.

Theorem 1. $(\mathbb{O},+, \circ)$ is a ring but not either an integral domain or a field.

Proof. We know that $(\mathbb{O},+)$ is a commutative group. On the other hands, we can write

$$
p \circ(q \circ r)=\left[p_{i} \vec{e}_{i}\right] \circ\left[q_{i} r_{i} \vec{e}_{i}\right]=p_{i} q_{i} r_{i} \vec{e}_{i}=\left[p_{i} q_{i} \vec{e}_{i}\right] \circ\left[r_{i} \vec{e}_{i}\right]=(p \circ q) \circ r
$$

and

$$
r \circ(p+q)=\left[r_{i} \vec{e}_{i}\right] \circ\left[\left(p_{i}+q_{i}\right) \vec{e}_{i}\right]=r_{i}\left(p_{i}+q_{i}\right) \vec{e}_{i}=r_{i} p_{i} \vec{e}_{i}+r_{i} q_{i} \vec{e}_{i}=r \circ p+r \circ q .
$$

Similarly, $(r+p) \circ q=r \circ q+p \circ q$ can be demonstrated. Now, we investigate the algebraic properties of $\left(\mathbb{O}^{\star}, \circ\right)$, where $\mathbb{O}^{\star}=\mathbb{O}-\{0\}$. It is clear that $\left(\mathbb{O}^{\star}, \circ\right)$ is closed, associative, distributive, and commutative. However, there are nonzero elements which are not invertible. For example, the element $q=\vec{e}_{1}+\vec{e}_{3}$ is nonzero and not invertible. Since $\left(\mathbb{O}^{\star}, \circ\right)$ is not a group, $(\mathbb{O},+, \circ)$ is not a field. We will prove that $(\mathbb{O},+, \circ)$ is not an integral domain later.

Unlike the usual product, the commutative law on the set $\mathbb{O}$ is valid for the Hadamard product. We denote the identity element under the Hadamard product by $\mathcal{I}$. Clearly, the identity $\mathcal{I}$ is a hypercomplex numbers with all entries equal to 1 , that is $\mathcal{I}=\vec{e}_{1}+\vec{e}_{2}+\ldots+\vec{e}_{2^{N}}$. In addition, we can conclude from the proof of Theorem 1 that a hypercomplex numbers $q$ has an inverse under the Hadamard product only if $q_{i} \neq 0$ for all $1 \leq i \leq 2^{N}$.

Remark 1. According to Theorem $1,(\mathbb{O},+, \circ)$ is a commutative and associative ring with an identity.

Throughout the paper, we will use the following notations under the Hadamard product: We denote the Hadamard inverse of $\mathrm{q}$ by $q^{\circ(-1)}$ and the iterated Hadamard product $\underbrace{p \circ p \circ \cdots \circ p}_{n \text { times }}$ by $q^{\circ(n)}$, that is $q^{\circ(n)}=p_{i}{ }^{n} \vec{e}_{i}$.

Theorem 2. The Hadamard product is linear.

Proof. To prove this theorem, we must show that the Hadamard product satisfies two conditions such that $r \circ(p+q)=r \circ p+r \circ q$ and $\alpha(p \circ q)=(\alpha p) \circ q=p \circ(\alpha q)$. We have already shown the first condition. It is sufficient to complete the proof that we show in the second condition. For $\alpha \in \mathbb{R}$, we can write

$$
\alpha(p \circ q)=\alpha\left(p_{i} q_{i} \vec{e}_{i}\right)=\left(\alpha p_{i}\right) q_{i} \vec{e}_{i}=(\alpha p) \circ q=p_{i}\left(\alpha q_{i}\right) \vec{e}_{i}=p \circ(\alpha q) .
$$

Thus, the theorem has been proved.

The next theorem presents certain fundamental properties.

Theorem 3. Let $p$ and $q$ be any two hypercomplex numbers. Then

i. $\overline{p \circ q}=\bar{p} \circ q=p \circ \bar{q}$

ii. $\bar{p} \circ p=p \circ \bar{p}=\overline{p^{\circ(2)}}$

iii. $(p \circ q)^{\circ(-1)}=p^{\circ(-1)} \circ q^{\circ(-1)}$, where $p$ and $q$ are invertible in the Hadamard sense.

Proof. We can write

$$
\overline{p \circ q}=\overline{\left(p_{i} q_{i} \vec{e}_{i}\right)}=p_{1} q_{1} \vec{e}_{1}-p_{l} q_{l} \vec{e}_{l}=p_{1} q_{1} \vec{e}_{1}+\left(-p_{l}\right) q_{l} \vec{e}_{l}=p_{1} q_{1} \vec{e}_{1}+p_{l}\left(-q_{l}\right) \vec{e}_{l} .
$$

The last two results give the the proof of 3.i. Similarly, we get

$$
p \circ \bar{p}=\bar{p} \circ p=\overline{\left(p_{i} \vec{e}_{i}\right)} \circ\left(q_{i} \vec{e}_{i}\right)=p_{1}^{2} \vec{e}_{1}-p_{l}^{2} \vec{e}_{l}=\overline{p^{\circ(2)}} .
$$


Finally,

and the result follows.

$$
(p \circ q)^{\circ(-1)}=\left(p_{i} q_{i} \vec{e}_{i}\right)^{\circ(-1)}=\frac{1}{p_{i} q_{i}} \vec{e}_{i},
$$

Theorem 4. $(\mathbb{O}, \circ)$ contains zero divisors and nontrivial idempotent elements but does not have nilpotent element.

Proof. Let $p$ and $q$ be two non-zero hypercomplex numbers whose coefficients satisfy one of the conditions such that $p_{i} \neq 0$ and $q_{i}=0$ or $p_{i}=0$ and $q_{i} \neq 0$. In this case, since $p_{i} q_{i}=0$, viz. $p \circ q=0$, we conclude that $(\mathbb{O}, \circ)$ has many zero divisiors for hypercomplex numbers in the form mentioned. Suppose that $p$ is not a unit hypercomplex numbers; further, suppose that the entries of $p$ are either 1 or 0 . Then, we can write that $p^{\circ(2)}=p$. Further, $p^{\circ(m)}=0$ only if $p_{i}^{m}=0$. As a result, $(\mathbb{O}, \circ)$ does not have nilpotent elements.

Theorem 5. Let $p$ and $q$ be any two hypercomplex numbers. Then, we have

$$
N(p \circ q) \leq N(p) N(q) .
$$

Proof. Considering Eq. (1), we write

$$
(N(p) N(q))^{2}=\left(\sum_{i=1}^{2^{N}} p_{i}{ }^{2}\right)\left(\sum_{i=1}^{2^{N}} q_{i}{ }^{2}\right)=\left(p_{i} q_{i}\right)^{2}+R\left(p_{i}, q_{i}\right),
$$

where $R\left(p_{i}, q_{i}\right)$ denotes the remaining terms. Since $R\left(p_{i}, q_{i}\right) \geq 0$, the desired result is obtained.

Remark 2. Theorem 5 indicates that $(\mathbb{O},+, \circ)$ is a normed algebra.

Theorem $6 .(\mathbb{O},+, \circ)$ is isomorphic to one of the following four algebras: the real numbers, the complex numbers, the quaternions, and the Cayley numbers.

Proof. The well-known Hurwitz's theorem states that every normed algebra with an identity is isomorphic to one of the following: the algebra of real numbers, the algebra of complex numbers, the algebra of quaternions, and the algebra of Cayley numbers. From Remarks 1 and 2, we can consider that $(\mathbb{O},+, \circ)$ is a normed algebra with an identity. Thus, the proof is completed.

We can say that Def. 1 has many applications in mathematics. One of the most important is that there are usages in the matrix theory. Let $A=\left(a_{k l}\right)$ and $B=\left(b_{k l}\right)$ be two $m \times n$ matrices, i.e., of the same dimension but not necessarily square. Then, the Hadamard product between these two matrices, denoted by $A \star B$, is an $m \times n$ matrix given by

$$
A \star B=\left(a_{k l} b_{k l}\right) .
$$

In our investigation, there are two various situations: Case (1) is the usual product of the hypercomplex numbers in the product element, i.e. $P \circledast Q=\left[p_{k l} q_{k l}\right]$; and Case (2) is the Hadamard product of the hypercomplex numbers in the product element, i.e. $P \odot Q=\left[p_{k l} \circ q_{k l}\right]$. Note that $p_{k l}$ and $q_{k l}$ are any $2^{N}$-ons hypercomplex numbers here.

A finite-dimensional associative algebra over any field $F$ is algebraically isomorphic to a sub-algebra of the full matrix algebra over the considered field. This means that each component in the finite-dimensional associative algebra has a faithful matrix representation over the field. Based on this motivation, we now define a bijective map

$$
\varphi: w=w_{1} \vec{e}_{1}+w_{2} \vec{e}_{2}+\cdots+w_{2^{N}} \vec{e}_{2^{N}} \in \mathbb{O} \rightarrow \varphi(w)=\left[[w] \vec{e}_{j}\right]_{2^{N} \times 2^{N}} .
$$

Here, the bracket is the vector representation of the corresponding quantity. Note that $\varphi(w)$ is a real skewsymmetric matrix. As an example, for $n=2$, we can write the matrix $\varphi(w)$ as

$$
\varphi(w)=\left[\begin{array}{cccc}
w_{0} & -w_{1} & -w_{2} & -w_{3} \\
w_{1} & w_{0} & -w_{3} & w_{2} \\
w_{2} & w_{3} & w_{0} & -w_{1} \\
w_{3} & -w_{2} & w_{1} & w_{0}
\end{array}\right]
$$

Hence, we can give the following significant result.

Corollary 1. $(\mathbb{O},+, \circ)$ is algebraically isomorphic to the matrix algebra

$$
\mathcal{M}=\left\{\left[[w] \vec{e}_{j}\right]_{2^{N} \times 2^{N}} \mid w \in \mathbb{O}\right\} .
$$


Further, $\varphi(w)$ is a faithful real matrix representation of $w$.

Next, we present the following result.

Lemma 1. Given any $w \in \mathbb{O}$, the following unitary similarity factorization equality is valid:

$$
\varphi(w)=\mathrm{M} D_{w} \mathrm{M}^{*},
$$

where $\mathrm{M}=(\sqrt{2})^{-N}\left[\vec{e}_{i} E_{N}\right], \mathrm{E}_{N}=\left[\begin{array}{lllll}\vec{e}_{1} & -\vec{e}_{2} & -\vec{e}_{3} & \ldots & -\vec{e}_{2^{N}}\end{array}\right]^{T}, \mathrm{M}^{*}$ means the complex conjugate of $\mathrm{M}$, and $D_{w}$ denotes a diagonal matrix such that while the entries outside main diagonal are zero, others are equal to $w$.

Proof. According to definition of $\mathrm{M}$, we can write that $\mathrm{M}^{*}=\mathrm{M}$. Hence, we can rearrange Eq. (3) as follows:

$$
\varphi(w) \mathrm{M}=\mathrm{M} D_{w} .
$$

Using the definition of matrix multiplication and the rules given in (2), the result follows.

We present our main result in the following.

Theorem \%. For any $u, v \in \mathbb{O}$, we have

$$
D_{u} \circledast D_{v}=\mathrm{M}^{*} \varphi(u v) \mathrm{M}
$$

and

$$
D_{u} \odot D_{v}=\mathrm{M}^{*} \varphi(u \circ v) \mathrm{M} .
$$

Proof. Applying matrix multiplication rule and Eq. (2) into each side of Eqs. (4) and (5), the results follow.

\section{References}

1 Hamilton, W.R. (1853). Lectures on quaternions. Hodges and Smith, Dublin.

2 Kravchenko, V.V. (2003). Applied quaternionic analysis. Heldermann Verlag, Germany.

3 Morais, J.P., Georgiev, S.G., \& Sprößig, W. (2014). Real Quaternionic Calculus Handbook. Springer.

4 Zhang, F. (1997). Quaternions and matrices of quaternions. Linear algebra and its applications, 251, $21-57$.

5 Horadam, A.F. (1963). Complex Fibonacci numbers and Fibonacci quaternions. The American Mathematical Monthly, 70(3), 289-291.

6 Tait, P.G. (1890). An elementary treatise on quaternions. University Press.

7 Kantor, I.L., \& Solodovnikov, A.S. (1989). Hypercomplex numbers: an elementary introduction to algebras. Springer.

8 Sabadini, I., \& Sommen, F. (Eds.). (2011). Hypercomplex analysis and applications. Birkhäuser.

9 Bernstein, S., Kähler, U., Sabadini, I., \& Sommen, F. (Eds.) (2014). Hypercomplex Analysis: New Perspectives and Applications. Springer International Publishing.

10 Cawagas, R.E. (2004). On the Structure and Zero Divisors of the Cayley-Dickson Sedenion Algebra. Discuss. Math. Gen. Algebra Appl., 24, 251-265.

\section{А. Дашдемир}

Кастамону университеті, Кастамону, Түркия

\section{Гиперкомплексті сандар Адамардың көбейтіндісі туралы}

Гиперкомплексті сандар жиынында әртүрлі форманы алатын белгілі бір көбейту ережелері бар болады. Мақалада нақты матрицалық кеңістіктегі көбейтуге ұқсас гиперкомплексті сандарды көбейтудің жаңа формасы енгізілген, ол «Адамар көбейтіндісі» деп аталады және оның кейбір алгебралық қасиеттері, соның ішінде норманың теңсіздігі зерттелген. Атап айтқанда, жаңа анықтамалар және оның қосымшалары комплексті матрицалар теориясына дейін кеңейтілген.

Kiлm сөздер: кватерниондардың көбейтіндісі, скаляр көбейтінді, Адамардың көбейтіндісі, гиперкомплексті сан. 
А. Дашдемир

Университет Кастамону, Кастамону, Туриия

\section{О произведении Адамара гиперкомплексных чисел}

Существуют определённые правила произведения, которые принимают различные формы на множестве гиперкомплексных чисел. В настоящей статье введена новая форма умножения гиперкомплексных чисел, которая будет называться «произведением Адамара», вдохновленная аналогичным произведением в вещественном матричном пространстве, и исследованы некоторые его алгебраические свойства, включая неравенство для нормы. В частности, автор статьи расширил определение и его приложения на теорию комплексных матриц.

Ключевые слова: произведение кватернионов, скалярное произведение, произведение Адамара, гиперкомплексное число. 